\title{
Expression of the heat shock gene clpL of Streptococcus thermophilus is induced by both heat and cold shock
}

\author{
Mario Varcamonti*1, Slavica Arsenijevic ${ }^{2}$, Luca Martirani ${ }^{1}$, Daniela Fusco ${ }^{3}$, \\ Gino Naclerio ${ }^{4}$ and Maurilio De Felice ${ }^{1}$
}

Address: ${ }^{1}$ Dept. of Structural and Functional Biology, University "Federico II", via Mezzocannone 16, 80134 Naples, Italy, ${ }^{2}$ Laboratory of Molecular Microbiology and Biotechnology, Department of Molecular Biology, University of Siena, Italy, ${ }^{3}$ Department of Experimental Pathology, Section on Microbiology and Virology, University of Bologna, Italy and 4 Faculty of Science, University of Molise, via Mazzini 8, 86170 Isernia, Italy

Email: Mario Varcamonti* - varcamon@unina.it; Slavica Arsenijevic - arsenijevic@unisi.it; Luca Martirani - 1.martirani@cemon.it; Daniela Fusco - danielafusco79@libero.it; Gino Naclerio - gino.naclerio@unimol.it; Maurilio De Felice - maurilio.defelice@unina.it

* Corresponding author

Published: 15 February 2006

Microbial Cell Factories2006, 5:6 doi:10.1/86/1475-2859-5-6
Received: 29 December 2005

Accepted: 15 February 2006

This article is available from: http://www.microbialcellfactories.com/content/5/1/6

(C) 2006Varcamonti et al; licensee BioMed Central Ltd.

This is an Open Access article distributed under the terms of the Creative Commons Attribution License (http://creativecommons.org/licenses/by/2.0), which permits unrestricted use, distribution, and reproduction in any medium, provided the original work is properly cited.

\begin{abstract}
Background: Heat and cold shock response are normally considered as independent phenomena. A small amount of evidence suggests instead that interactions may exist between them in two Lactococcus strains.

Results: We show the occurrence of molecular relationships between the mechanisms of cold and heat adaptations in Streptococcus thermophilus, a lactic acid bacterium widely used in dairy fermentation, where it undergoes both types of stress. We observed that cryotolerance is increased when cells are pre-incubated at high temperature. In addition, the production of a protein, identified as ClpL, a member of the heat-shock ATPase family Clp A/B, is induced at both high and low temperature. A knock-out $c / p L$ mutant is deficient in both heat and cold tolerance. However lack of production of this protein does not abolish the positive effect of heat pretreatment towards cryotolerance.

Conclusion: Dual induction of ClpL by cold and heat exposure of cells and reduced tolerance to both temperature shocks in a $c / p L$ mutant indicates that the two stress responses are correlated in $S$. thermophilus. However this protein is not responsible by itself for cryotolerance of cells pretreated at high temperature, indicating that ClpL is necessary for the two phenomena, but does not account by itself for the relationships between them.
\end{abstract}

\section{Background}

Although cold and heat shock are normally considered as independent processes, recent evidence points to the occurrence of interlock between them is some organisms. Physiological experiments suggest that cold-shock enhances heat tolerance of Lactococcus lactis sp. lactis IL1403 [1]. Possible correlations between the heat and cold shock regulons were suggested by i) the observation of an increased level of Leuconostoc mesenteroides homologues of the heat shock proteins DnaK and GroEL upon cold-shock [2], ii) the cold induction of a group of small heat shock genes in Lactobacillus plantarum $[3,4]$ and iii) a slight protection from freezing of Lactobacillus johnsonii [5] and $L c$. lactis sp. lactis [6] cells upon induction of the heatshock response. Conversely, heat-shock did not improve 


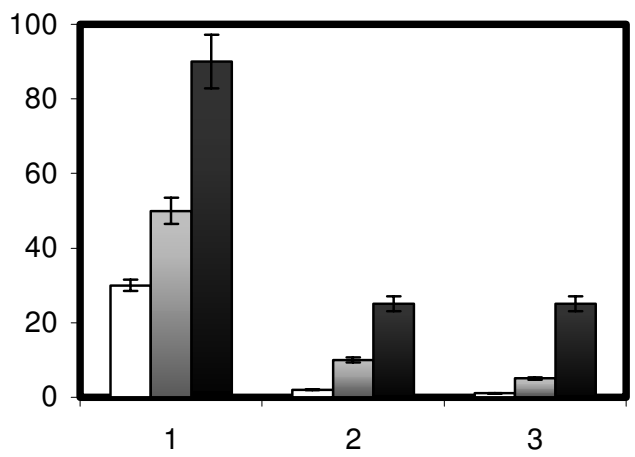

Figure I

Survival of S. thermophilus SFi39 after freezing upon direct freezing from $42^{\circ} \mathrm{C}$ (white bar), heat-shock pre-adaptation (gray bar) and cold-shock pre-adaptation (black bar). Survival ( $y$-axis) is expressed as the percentage of surviving cells compared to the number of cells prior to freezing (100). Cells survival was tested one, two and three days ( $x$-axis) after freezing. Error bars indicate the coefficient of variation in different experiments.

cryotolerance of Lc lactis sp. cremoris strain MG1363 [7], suggesting a strain specificity of this phenomenon.

An unidentified cold-inducible 45-kDa protein of Lc lactis [8] was proposed to correspond to the heat-inducible ClpX ATPase [9], a member of the large family of closely related ATPases found in both prokaryotic and eukaryotic cells [10], having multiple regulatory functions, included a general chaperone activity and the ability to enable the Clp proteases to recognize their substrates $[11,12]$. Thus a ClpX function may be to promote the proteolysis of misfolded proteins after both cold or heat-shock.

In order to gain a deeper insight into the correlation between cold and heat shock, we analyzed the phenomenon in Streptococcus thermophilus, a moderate thermophilic LAB widely used in dairy fermentation, where cold and heat stresses are common. Here we show that the synthesis of a $75 \mathrm{kDa}$ protein is induced in both conditions and this induction is essential for stress tolerance.

\section{Results and discussion Influence of heat and cold shock on S. thermophilus cryotolerance}

In order to investigate whether cryotolerance of $S$. thermophilus cells during storage is improved by cold- and/or heat-shock, aliquots of cells grown to middle exponential phase at $42^{\circ} \mathrm{C}$ were exposed to high and low temperature shocks $\left(30 \mathrm{~min}\right.$ at $50^{\circ} \mathrm{C}$ and $4 \mathrm{~h}$ at $20^{\circ} \mathrm{C}$, respectively), then fractions of live cells were analyzed after one, two and three days of freeze challenge. Fig. 1 shows that cold shock treatment gives a high protection to freezing, and, in analogy to observations with $L b$. johnsonii [5] and $L c$. lactis sp. lactis [6], an induction of the heat-shock response gives a slight protection from freezing.

Enhanced cryotolerance was not detected when erythromycin was present at sublethal concentration $(2 \mu \mathrm{g} / \mathrm{ml})$ during heat and cold shock treatments (not shown), which indicated that de novo synthesis of proteins is essential for freezing survival. This is not surprising, since, for example, it is known that GroEL and DnaK are induced by heat and cold stress in other LAB [4] and are involved in heat and cold tolerance of Escherichia coli [13].

\section{Heat and cold induction of a $75 \mathrm{kDa}$ protein}

In order to look for proteins induced by heat and cold stresses, we performed a protein extraction followed by SDS PAGE after exposure of $S$. thermophilus cells to the two temperature shocks. In addition to a few bands most likely corresponding to well known proteins accumulated during the early phase of the heat shock response, a band of apparent molecular mass of $75 \mathrm{kDa}$ was induced by both heat and cold (fig. 2). The two bands were eluted from the HS and CS lanes and N-terminal sequenced. The first 13 amino acids (MNNNFNNMDDLFN) were the same for both and were identical to those of the ClpL protein of S. thermophilus [14] and to a previously reported 75 $\mathrm{kDa}$ heat shock induced protein [15]. Based on the N-terminal 10 amino acids of the identified protein, we synthesized a $30 \mathrm{~b}$ oligonucleotide that was used to perform Southern hybridization with the KpnI-digested SFi39 chromosome. A 1500 bp fragment was isolated, cloned and sequenced; one 300 aa ORF starting with the expected 13 amino acids was identified (fig. 3) and resulted 99\% identical to the class III heat shock protein ClpL of $S$. thermophilus CNRZ1066, a member of the ClpA/B ATPase family [16].

Most class III heat shock genes are controlled by the class III stress gene repressor CtsR, which binds to a specific direct repeat referred to as CtsR-box [17]. The promoter region of many clp genes contains a sequence homologous to the CtsR box (a directly repeated heptanucleotide, A/GGTCAAANANA/G GTCAAA) [17].

In other LAB, CtsR operators were also found upstream of several $c l p$ genes (L. sakei and S. salivarius) [17] and $c l p P$, clpE, clpL, cstR-clpC genes of S. pneumoniae [18] and other Hsp encoding genes, Lo18 of Oenococcus oeni, hsp16 of S. thermophilus [17] and groESL of S. pneumoniae [18]. A putative CtsR consensus sequence is also present in the promoter region of the Sfi39 clpL gene (fig. 3), 44 base pairs upstream of the first transcribed nucleotide (identified by primer extension analysis, data not shown). 


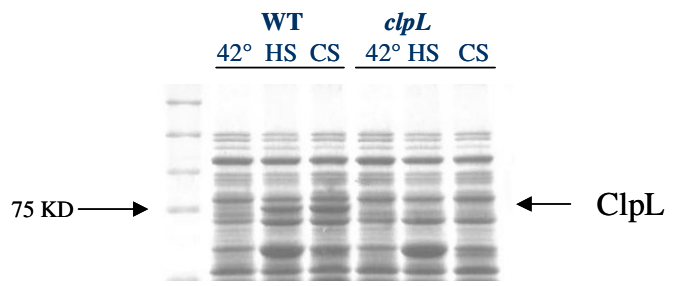

Figure 2

SDS-PAGE of cell extracts of $S$. thermophilus SFi39, wild type and $c \mid p L \Delta$, after growth at $42^{\circ} \mathrm{C}$ (lanes I and 4), after heat shock induction (lanes 2 and 5 ) and cold shock induction (lanes 3 and 6). Equal amounts of protein were loaded on the gel.

clpL disruption reduces tolerance to heat and cold shock In order to understand the function of ClpL in $S$. thermophilus, we constructed a SFi39 mutant by cloning an internal fragment of the gene in the $\mathrm{pG}+$ host9 vector [19]. SFi39 cells were transformed with the recombinant plasmid and forced for homologous recombination of the plasmid into the chromosome. Chromosomal DNA isolated from both wild-type and erythromycin-resistant cells was analyzed by Southern blotting using a specific $c l p L$ sequence as a probe. The absence of gene product in the mutant was confirmed by showing that the ClpL band present in the wild type was not present in the transformed strain (fig. 2). The mutant obtained was named clpLA.

Cells from the two strains were grown to middle exponential phase at $42^{\circ} \mathrm{C}$. No difference in growth rate was observed in these conditions. The cells were then heatshocked at $60^{\circ} \mathrm{C}$ for 1 hour. As shown in fig. 4, clpL $\Delta$ cells were less tolerant to heat-shock: one wild type cell out of ten survived to the treatment, whereas mutant survival decreased dramatically to 1 cell out of 100,000. This result demonstrates that ClpL, in analogy to well known proteins such as GroEL and DnaK, is involved in the protection of cells against heat.

Cold shock tolerance at $20^{\circ} \mathrm{C}$ of the mutant was tested by measuring its growth, compared to the wild type, after temperature downshift of cells pre-grown exponentially at $42^{\circ} \mathrm{C}$. As shown in fig. 5 , growth of the wild type continued after temperature downshift at a reduced rate as expected, whereas the clpL mutant had to face a long lag phase before restoration of growth at a rate comparable to that of the wild type, which suggests that $\mathrm{ClpL}$ is required for normal response to cold shock.

The slight protection from freezing of previously heatshocked wild type cells shown in fig. 1 was observed also with the ClpL mutant (data not shown), which indicates that the molecular relationship between cold and heat stresses is a complex phenomenon in which the ClpL protein plays only part of the role.

\section{Conclusion}

It is well established that bacteria display adaptive systems to adjust their metabolism to cold and heat shocks. We show that pre-incubation of $S$. thermophilus cells at both high and low temperature enhances their resistance to freezing conditions, which supports the idea that cold and heat shocks, normally considered as unrelated phenomena, have in fact some relationships. At least one shockinduced factor, the ClpL protein, is involved in both phenomena, since we show that i) its synthesis is enhanced in

$$
\text { CtsRbox } \quad-35 \quad-10
$$

TGGTCAGTAAAAGTCAAATTTTACACATTAACTAAAATAACACTTAAAAAATCACAAGAAA

\author{
RBS \\ ACACAGTATGAGGTGATTATATGAACAACAACTTTAATAATATGGATGATCTTTTCAATCAAT \\ $\begin{array}{llllllllllllll}M & \mathrm{~N} & \mathrm{~N} & \mathrm{~N} & \mathrm{~F} & \mathrm{~N} & \mathrm{~N} & \mathrm{M} & \mathrm{D} & \mathrm{D} & \mathrm{L} & \mathrm{F} & \mathrm{N} & \mathrm{Q}\end{array}$
}

TGATGGGTAACATGGGTGGTTTCCGTTCAGAAAGCCGTCGCTACATGATTAACGGTCG.//

$\begin{array}{llllllllllllllllllll}\mathrm{L} & \mathrm{M} & \mathrm{G} & \mathrm{N} & \mathrm{M} & \mathrm{G} & \mathrm{G} & \mathrm{F} & \mathrm{R} & \mathrm{S} & \mathrm{E} & \mathrm{S} & \mathrm{R} & \mathrm{R} & \mathrm{Y} & \mathrm{M} & \mathrm{I} & \mathrm{N} & \mathrm{G} & \mathrm{R} . . . / /\end{array}$

\title{
AAAGAAAAAAATGCTAAATAAAAAGCATAGGAACTCCTAATCCGATTAATGAAGCAGAG $\begin{array}{llllllllll}\mathrm{K} & \mathrm{E} & \mathrm{K} & \mathrm{N} & \mathrm{A} & \mathrm{K} & -\end{array}$
}

\section{Figure 3}

Promoter region and $\mathrm{N}$-terminal domain of ClpL. The CtsR box, promoter sequences and putative RBS are underlined. The first nucleotide transcribed and the $\mathrm{N}$-terminal amino acids sequenced are in bold. 


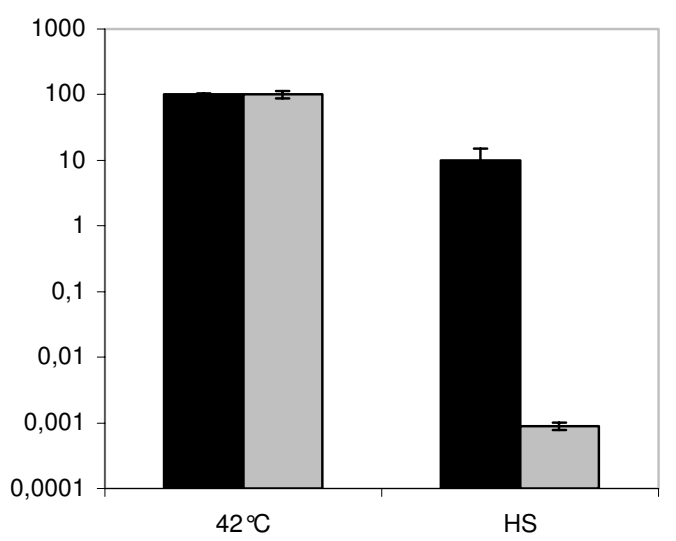

Figure 4

Streptococcus thermophilus SFi39 (black bars) and clpL $\Delta$ (gray bars) survival upon induction of heat shock (HS). Survival is reported as the percentage (y-axis) of colony-forming cells after the treatment compared to that after growth at $42^{\circ} \mathrm{C}$ $(100 \%)$. Error bars indicate the coefficient of variation in three different experiments.

both conditions and ii) no correct response to either stress is observed in a clpL knock-out mutant. The finding that this protein is not responsible by itself for the observed phenomenon of cryotolerance of cells pretreated at high temperature indicates that $\mathrm{ClpL}$, although necessary for correct response to both heat and cold stressess, does not account by itself for the moleculr relationships between them, which are most likely based on a more complex regulatory network.

\section{Methods}

\section{Bacterial strains and growth conditions}

S. thermophilus SFi39 was cultured at $42^{\circ} \mathrm{C}$ in M17 broth (Oxoid) containing 1\% lactose. Growth was monitored by measuring the optical density at $600 \mathrm{~nm}$ (OD600) with a JAS.CO spectrophotometer (model 7800). Erythromycin was added at a concentration of $4 \mu \mathrm{g} / \mathrm{ml}$. E. coli DH5 $\alpha$ and EC101 were used as host strains in cloning experiments and were grown in Tryptone Yeast (TY) medium with aeration at $37^{\circ} \mathrm{C}[20]$. Ampicillin and erythromycin were used at concentrations of 50 and $100 \mu \mathrm{g} / \mathrm{ml}$, respectively. To study growth kinetics, $1 \%$ inoculated cultures were grown at different temperatures. Growth was monitored by measuring the optical density at $600 \mathrm{~nm}$ (OD600).

\section{Freeze-thaw challenge}

To study the freeze-thaw survival capacity, with or without preadaptation, $S$. thermophilus cells were quickly frozen at middle exponential phase $(\mathrm{OD} 600=0.5)$, after heat $(30$ min at $50^{\circ} \mathrm{C}$ ) and cold shock $\left(4 \mathrm{~h}\right.$ at $\left.20^{\circ} \mathrm{C}\right)$. Aliquots $(1$

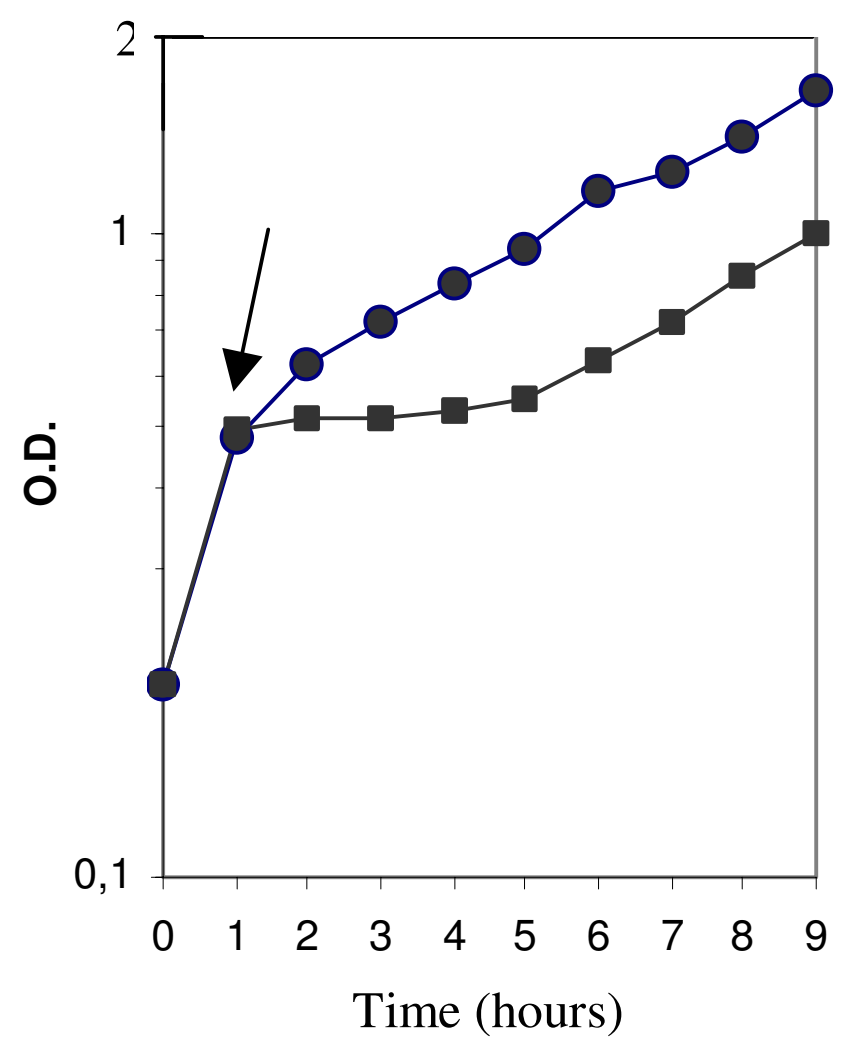

Figure 5

Growth curves of SFi39 (circles) and clpL $\Delta$ (squares). After the first hour of incubation at $42^{\circ} \mathrm{C}$ (arrow) cells were incubated at $20^{\circ} \mathrm{C}$.

$\mathrm{ml}$ ) were spun down (5 min at $6000 \mathrm{rpm})$, resuspended in $1 \mathrm{ml}$ of fresh LM17 medium, subsequently frozen at $20^{\circ} \mathrm{C}$ for $24 \mathrm{~h}$, and thawed for $4 \mathrm{~min}$ at $30^{\circ} \mathrm{C}$ in a water bath. The number of CFU was determined just before freezing and after three consecutive freeze-thaw challenges by spread plating decimal dilutions. After 2-day incubations on LM 17 plates at $42^{\circ} \mathrm{C}$ the numbers of CFU were counted. The experiments were performed in duplicate. Coefficient of variation was $<10 \%$.

\section{Protein extraction and protein analysis by SDS-PAGE gel electrophoresis}

Protein extracts were obtained according to [21] and protein concentration was determined by the "BIO-RAD protein assay" method. Protein analysis was performed using SDS PAGE. Equal amounts of protein $(15 \mu \mathrm{g})$ were applied on the protein gels and the protein content of the extract was determined using Coomassie Brilliant Blue.

\section{N-terminal sequencing}

$500 \mu \mathrm{g}$ of protein was loaded on SDS-PAGE gel for detection of the $\mathrm{N}$-terminus of specific bands using conditions identical to the analytical gels. The proteins were blotted 
on a PVDF membrane using a Trans blot unit according to the instruction of the manufacturer (Biorad, Richmond, USA). The PVDF membrane containing separated proteins was stained 1 min with Coomassie Brilliant Blue R$250(0.1 \%$ in water containing 50\% methanol), destained for about $10 \mathrm{~min}$ in a solution of $40 \%$ methanol plus $10 \%$ acidic acid in water, and washed in water. Stained protein band was cut from the membrane and subjected to the Edman procedure. BlastP http://www.ncbi.nlm. nih.gov/ BLAST/BLAST.cgi was used to search for similarity in public protein databases.

Southern hybridization with degenerated oligonucleotide Based on the $10 \mathrm{~N}$-terminal amino acids of the isolated protein (MNNNFNNMDD) a 30 b degenerated oligonucleotide was synthesized (5'-ATGAAYAAYAAYTTYAAYAAYATGGAYGAY-3'; Y=T/C) and used in Southern hybridization with chromosomal DNA. Southern hybridization was performed at $37^{\circ} \mathrm{C}$ overnight, and the membrane was washed $2 \mathrm{~min}$ at $37^{\circ} \mathrm{C}$ in $3 \mathrm{XSSC}, 0.1 \%$ SDS and $2 \mathrm{~min}$ at $37^{\circ} \mathrm{C}$ in $2 \mathrm{XSSC}, 0.1 \%$ SDS, before exposure to $\mathrm{X}$ Ray film [17]. The probe was labeled with polynucleotide kinase (Pharmacia, Biotech) ([ $\gamma-32 \mathrm{P}]-\mathrm{ATP}$.

\section{DNA manipulations}

Chromosomal $S$. thermophilus DNA was isolated as described previously [22]. Cells were transformed by electroporation. E. coli cells were transformed by the $\mathrm{CaCl} 2$ procedure and plasmid isolation was carried out according to standard procedures [20]. Restriction enzymes, T4 DNA ligase and other DNA-modifying enzymes were purchased from Gibco-BRL Life Technologies, New England Biolabs or Promega, and used as recommended by the manifacturers. Cloning procedures, radiolabelling of DNA fragments, agarose gel electrophoresis and Southern-blot hybridization were performed according to standard procedures [20]. DNA fragments were isolated from agarose gels by using the QIAquick gel extraction Kit (QIAGEN).

\section{Construction of the clpL insertional mutant}

To construct an insertional mutant with a disruption in the S. thermophilus clpL gene, a 1500 bp PCR fragment (HCIDWF primer: 5'-CTTTTCAATCAATTG ATGGG-3'; HCIDEL482 primer: CATTTGWGAWACWGGRATWCCWGTCAT-3') was amplifed and cloned in the pG+host9 integrational vector [19] digested with EcoRI-SpeI and the resulting plasmid was designated pGh482. 1 × 108 S. thermophilus competent cells were mixed with 500 ng of plasmid pGh482 and electroporated [23]. Transformed cells were grown in anaerobic conditions in the presence of 4 $\mu \mathrm{g}$ erythromycin ml- 1 at permissive temperature $\left(30^{\circ} \mathrm{C}\right)$, to allow plasmid replication. Integration of pGh482 into the $S$. thermophilus chromosome was forced by growing cells at $30^{\circ} \mathrm{C}$ up to $0.2-0.3 \mathrm{OD} 600$, then shifting to $42^{\circ} \mathrm{C}$ and allowing cell growth for two generations (up to 1.21.5 OD600). Cells were then diluted and plated on LM17 plates supplemented with $4 \mu \mathrm{g}$ erythromycin ml-1 and incubated anaerobically at $42^{\circ} \mathrm{C}$.

\section{Stress tolerance}

For heat shock treatment, exponentially growing cells (OD600 $=0.5$ ) of Sfi39 and $c l p L$ mutant were transferred to $60^{\circ} \mathrm{C}$ for $1 \mathrm{~h}$. Cell survival was measured by plating on LM17 at $42^{\circ} \mathrm{C}$ before and after incubation at $60^{\circ} \mathrm{C}$. For cold-shock treatments $50 \mathrm{ml}$ cultures of Sfi39 and $c l p L$ mutant were grown in LM17 medium to middle exponential phase $(\mathrm{OD} 600=0.5)$, after which $25 \mathrm{ml}$ of the culture were pelleted (10 $\mathrm{min} \times 4000 \mathrm{~g}$ ) and re-suspended in the same volume of pre-cooled medium $\left(20^{\circ} \mathrm{C}\right)$. Cultures were incubated at $20^{\circ} \mathrm{C}$ and OD600 values were measured.

\section{Authors' contributions}

MV had a predominant role in the design and implementation of the study and in the preparation of the manuscript, SA performed the identification and cloning of the clpL gene and the construction of $S$. thermophilus mutant, LM carried out the protein preparation for Edman sequencing, DF and GN partecipated in the characterization of $c l p L$ mutant phenotype, MDF helped with discussions and suggestions during the work, preparation of the manuscript and funding. All authors read and approved the final manuscript.

\section{Acknowledgements}

This work was partially supported by Centro Regionale di Competenza BioTekNet, Naples, Italy.

\section{References}

I. Panoff JM, Thammavongs B, Laplace A, Hartke A, Boutibonnes P, Auffray $Y$ : Cryotolerance and cold adaptation in Lactococcus lactis subsp. lactis IL | 403. Cryobiol I995, 32:5 I 6-520.

2. Salotra P, Singh DK, Seal KP, Krishna N, Jaffe H, Bhatnagar R: Expression of DnaK and GroEL homologs in Leuconostoc mesenteroides in response to heat shock, cold shock or chemical stress. FEMS Microbiol lett 1995, I 3 1:57-62.

3. Spano G, Capozzi V, Vernile A, Massa S: Cloning, molecular characterization and expression analysis of two small heat shock genes isolated from wine Lactobacillus plantarum. Journal of Applied Microbiol 2004, 97:774-782.

4. Spano G, Beneduce L, Perrotta C, Massa S: Cloning and characterization of the hsp I8.55 gene, a new member of the small heat shock genes family isolated from wine Lactobacillus plantarum. Research in Microbiol 2005, 200:19-224.

5. Walker DC, Girgis HS, Klaenhammer TR: The groESL chaperone operon of Lactobacillus johnsonii. Appl Environ Microbiol 1999, 65:3033-4I.

6. Broadbent JR, Lin C: Effect of heat shock or cold shock treatment on the resistance of Lactococcus lactis to freezing and lyophilization. Cryobiol 1999, 39:88-102.

7. Wouters JA, Jeynov B, Rombouts FM, de Vos WM, Kuipers OP, Abee $\mathrm{T}$ : Analysis of the role of $\mathbf{7} \mathbf{~ k D a}$ cold- shock proteins of Lactococcus lactis MGI363 in cryoprotection. Microbiology 1999, | 45:3185-94.

8. Wouters JA, Rombouts FM, de Vos WM, Kuipers OP, Abee T: Cold shock proteins and low-temperature response of Streptococcus thermophilus CNRZ302. Appl Environ Microbiol 1999, 65:4436-42. 
9. Skinner MM, Trempy JE: Expression of clpX, an ATPase subunit of the Clp protease, is heat and cold shock inducible in Lactococcus lactis. J Dairy Sci 200I, 84: I783-5.

10. Schirmer EC, Glover JR, Singer MA, Lindquist S: HSP I 00/Clp proteins: a common mechanism explains diverse functions. Trends Biochem Sci 1996, 21:289-96.

II. Wawrzynow A, Wojtkowiak D, Marszalek J, Banecki B, Jonsen M, Graves B, Georgopoulos C, Zylicz M: The ClpX heat-shock protein of Escherichia coli, the ATP-dependent substrate specificity component of the ClpP-ClpX protease, is a novel molecular chaperone. EMBO J 1995, I 4:1867-77.

12. Wickner S, Gottesman S, Skowyra D, Hoskins J, McKenney K, Maurizi MR: A molecular chaperone, ClpA, functions like DnaK and DnaJ. Proc Natl Acad Sci U S A 1994, 91 : I 22 I 8-22.

13. Chow KC, Tung WL: Overexpression of dnaK/dnaJ and groEL confers freeze tolerance to Escherichia coli. Biochem Biophys Res Commun 1998, 253:502-5.

14. Bolotin A, Quinquis B, Renault P, Sorokin A, Ehrlich SD, Kulakauskas S, Lapidus A, Goltsman E, Mazur M, Pusch GD, Fonstein M, Overbeek R, Kyprides N, Purnelle B, Prozzi D, Ngui K, Masuy D, Hancy F, Burteau S, Boutry M, Delcour J, Goffeau A, Hols P: Complete sequence and comparative genome analysis of the dairy bacterium Streptococcus thermophilus. Nat Biotechnol 2004, 22: 1554-8.

15. Giliberti G, Naclerio G, Martirani L, Ricca E, De Felice M: Alteration of cell morphology and viability in a recA mutant of Streptococcus thermophilus upon induction of heat shock and nutrient starvation. Gene 2002, 295: I-6.

16. Huang DC, Huang XF, Novel G, Novel M: Two genes present on a transposon-like structure in Lactococcus lactis are involved in a Clp-family proteolytic activity. Mol Microbiol 1993, 7:957-65.

17. Derre I, Rapoport G, Devine K, Rose M, Msadek T: ClpE, a novel type of HSP 100 ATPase, is part of the CtsR heat shock regulon of Bacillus subtilis. Mol Microbiol 1999, 32:58I-93.

18. Chastanet A, Prudhomme M, Claverys JP, Msadek T: Regulation of Streptococcus pneumoniae clp genes and their role in competence development and stress survival. I Bacteriol 200I, 183:7295-307.

19. Maguin E, Prèvost $H$, Ehrlich SD, Gruss A: Efficient insertional mutagenesis in Lactococci and other Gram-positive bacteria. J Bacteriol 1996, I 78:931-935.

20. Sambrook J, Fritsch EF, Maniatis T: Molecular cloning. A laboratory manual. second edition. Cold Spring Harbor Laboratory Press, Cold Spring Harbor, NY; 1989.

21. Gonzalez-Marquez H, Perrin C, Bracquart P, Guimont C, Linden G: A $16 \mathrm{kDa}$ protein family overexpressed by Streptococcus thermophilus PBI8 in acid environments. Microbiology 1997 I 43: I587-94.

22. Limauro D, Falciatore A, Basso AL, Forlani G, De Felice M: Proline biosynthesis in Streptococcus thermophilus: characterization of the proBA operon and its products. Microbiology 1996 I 42:3275-82.

23. Baccigalupi L, Naclerio G, De Felice M, Ricca E: Efficient insertional mutagenesis in Streptococcus thermophilus. Gene 2000, 258:9-14.

\section{Publish with Bio Med Central and every} scientist can read your work free of charge

"BioMed Central will be the most significant development for disseminating the results of biomedical research in our lifetime. "

Sir Paul Nurse, Cancer Research UK

Your research papers will be:

- available free of charge to the entire biomedical community

- peer reviewed and published immediately upon acceptance

- cited in PubMed and archived on PubMed Central

- yours - you keep the copyright
BioMedcentral 